\title{
Morpho-Physiological Characterization of Glyphosate-Resistant and -Susceptible Horseweed (Conyza canadensis) Biotypes of US Midsouth
}

\author{
Vijay K. Nandula ${ }^{1 *}$, Daniel H. Poston${ }^{2}$, Clifford H. Koger ${ }^{3}$, Krishna N. Reddy ${ }^{1}$, \\ K. Raja Reddy ${ }^{4}$ \\ ${ }^{1}$ US Department of Agriculture-Agricultural Research Service (USDA-ARS), Crop Production Systems Research \\ Unit, Stoneville, MS, USA \\ ${ }^{2}$ Pioneer Hi-Bred International-Southern Business Unit, Huntsville, AL, USA \\ ${ }^{3}$ Silent Shade Planting Company, Belzoni, MS, USA \\ ${ }^{4}$ Department of Plant and Soil Sciences, Mississippi State University, Mississippi State, MS, USA \\ Email: vijay.nandula@ars.usda.gov
}

Received 13 December 2014; revised 28 December 2014; accepted 8 January 2015

Copyright (C) 2015 by authors and Scientific Research Publishing Inc.

This work is licensed under the Creative Commons Attribution International License (CC BY). http://creativecommons.org/licenses/by/4.0/

(c) (i) Open Access

\section{Abstract}

Horseweed is traditionally considered a non-cropland weed. However, populations resistant to glyphosate have eventually become established in no-till agronomic cropping systems. Growth chamber and greenhouse experiments were conducted to compare selected biological and physiological parameters of glyphosate-resistant (GR) and -susceptible (GS) horseweed biotypes from Mississippi with a broader goal of fitness characterization in these biotypes. Vegetative growth parameters (number of leaves, rosette diameter and area, shoot and root fresh weights) were recorded weekly from 5 to $11 \mathrm{wk}$ after emergence and reproductive attributes [days to bolting (production of a flowering stalk) and flowering] and senescence were measured for both GR and GS biotypes under high $\left(24^{\circ} \mathrm{C} / 20^{\circ} \mathrm{C}\right)$ and low $\left(18^{\circ} \mathrm{C} / 12^{\circ} \mathrm{C}\right)$ temperature regimes, both with a 13-h light period. Physiological traits such as net photosynthesis, phenolic content, and cell membrane thermostability, all in the presence and absence of glyphosate, and leaf content of divalent cations such as $\mathrm{Ca}^{2+}$ and $\mathrm{Mg}^{2+}$ were assayed in the two biotypes under the high temperature regime. All horseweed vegetative growth parameters except root fresh weight were higher in the high temperature regime compared to that in low temperature regime in both biotypes. Number of leaves, rosette diameter and area, shoot and root fresh weight were $40 \mathrm{vs} .35,9.3 \mathrm{vs} .8 .7 \mathrm{~cm}, 51 \mathrm{vs} .43 \mathrm{~cm}^{2}$, 3.7 vs. $3.2 \mathrm{~g}$, and $3.5 \mathrm{vs}$. $4.2 \mathrm{~g}$ under high and low temperature conditions, respectively, when av-

\footnotetext{
${ }^{*}$ Corresponding author.
}

How to cite this paper: Nandula, V.K., Poston, D.H., Koger, C.H., Reddy, K.N. and Reddy, K.R. (2015) Morpho-Physiological Characterization of Glyphosate-Resistant and -Susceptible Horseweed (Conyza canadensis) Biotypes of US Midsouth. American Journal of Plant Sciences, 6, 47-56. http://dx.doi.org/10.4236/ajps.2015.61006 
eraged across biotypes and weekly measurements. All growth parameters listed above were higher for the GR biotype compared to the GS biotype. Number of leaves, rosette diameter and area, shoot and root fresh weight were 38 vs. $37,9.1$ vs. $8.9 \mathrm{~cm}, 50.2$ vs. $44 \mathrm{~cm}^{2}, 3.9 \mathrm{vs} .3 .1 \mathrm{~g}$, and 4.3 vs. $3.5 \mathrm{~g}$ for GR and GS biotypes, respectively, averaged across the temperature treatments and weekly measurements. Reproductive developmental data of these biotypes indicated that the GS biotype bolted earlier than the GR biotype. The GS biotype had more phenolic content and exhibited higher cell membrane thermostability, but less net photosynthetic rate compared to the GR biotype. At $48 \mathrm{~h}$ after treatment with glyphosate, there was no change in phenolic content of both GR and GS biotypes. However, glyphosate reduced cell membrane thermostability and net photosynthetic rate more in the GS biotype than that in the GR biotype. Chemical analysis of GR and GS leaf tissue did not reveal any differences in levels of divalent cations such as $\mathrm{Ca}^{2+}$ and $\mathrm{Mg}^{2+}$. Further studies are needed to determine if some of the differences between the two biotypes observed above relate to fitness variation in a natural environment.

\section{Keywords}

Conyza canadensis, Glyphosate, Growth, Fitness, Horseweed, Resistance

\section{Introduction}

Horseweed, also referred to as butterweed, coltstail, fleabane, or marestail, is an annual plant native to North America and Central America [1]. Horseweed thrives in conservation- or no-tillage systems [2] [3], but is susceptible to common tillage practices of conventional tillage cropping systems [4]. Increasing adoption of herbicide-resistant crop technology, especially glyphosate-resistant crops, has encouraged reduced and no-till production practices. This switch in management strategy has encouraged traditionally noncropland weeds such as horseweed to migrate into and infest cropland. Compounding this problem, horseweed populations have developed resistance to glyphosate in several states across the US [5]-[8].

Glyphosate-resistant (GR) horseweed biotypes from Mississippi were 8- to 12-fold more resistant to glyphosate than a glyphosate-susceptible (GS) biotype [7]. Koger and Reddy [9] reported 28\% reduced translocation of 14C-glyphosate from the treated leaf of a GR biotype from Mississippi compared with a GS biotype. They suggest that reduced translocation of glyphosate to growing parts of the GR plant has a role in glyphosate resistance mechanism [9]. It is not clear that growth differences, if any, between the GR and GS biotypes explain the differential resistance between the two biotypes. Therefore, it is important to understand morpho-physiological variability and differences between the GR and corresponding GS biotypes and make a connection to biological fitness of GR horseweed biotypes. Further, potential differences between the GR and GS biotypes in common physiological traits could provide new insights into the glyphosate resistance mechanism.

Any inherent growth and developmental differences between GR and GS biotypes may impact management strategies such as preplant burndown, preemergence, or postemergence herbicide applications. Inadequate control of GR horseweed biotypes could cause a reduction in yield by competing for resources such as nutrients, soil moisture, and sunlight with GR soybean, cotton, or corn plants. Another consequence of inadequate control of GR horseweed biotypes could be plants going to seed and adding to the soil seed bank, thereby, reducing management options for the future. To date, there has been no information on growth and developmental variability differences between GR and GS horseweed biotypes originating from an agronomic cropping region. The objective of this study was to characterize morhpo-physiological differences between noncompetitively-grown GR and GS horseweed biotypes collected from US Midsouth area.

\section{Materials and Methods}

\subsection{Plant Materials and Growing Conditions}

Seeds of GR and GS horseweed biotypes, collected from field-grown plants in Mississippi (Koger et al. 2004), were planted in $12.5 \mathrm{~cm}$ by $10 \mathrm{~cm}$ by $6 \mathrm{~cm}$ plastic trays containing a mixture of field soil (Bosket sandy loam, 
fine-loamy, mixed, thermic Mollic Hapludalfs) and potting mix (Jiffy Products of America Inc., Batavia, IL, USA) (1:1 by volume). Trays were covered with a plastic wrap and placed in a greenhouse $\left(32^{\circ} \mathrm{C} / 25^{\circ} \mathrm{C} \pm 3^{\circ} \mathrm{C}\right.$ day/night temperature; natural light supplemented with light from sodium vapor lamps to provide a 13-h photoperiod). After emergence, seedlings in the cotyledon stage (1 wk after emergence, WAE) were transplanted to individual 10-cm-diam by 10 -cm-deep plastic pots containing soil mix described above. Plants were transferred to two different growth chambers calibrated for high $\left(24^{\circ} \mathrm{C} / 20^{\circ} \mathrm{C}\right)$ and low $\left(18^{\circ} \mathrm{C} / 12^{\circ} \mathrm{C}\right)$ day/night temperature regimes. Photoperiod was set at $13 \mathrm{~h}$ to coincide at maximum temperature within each regime. Fluorescent and incandescent lamps were used to produce a photosynthetic photon flux density of $600 \mathrm{mmol} \cdot \mathrm{m}^{-2} \cdot \mathrm{s}^{-1}$. Two weeks after transplanting plants were fertilized with a nutrient solution (W. R. Grace and Co., Fogelsville, PA, USA) containing $200 \mathrm{mg} \cdot \mathrm{L}^{-1}$ each of $\mathrm{N}, \mathrm{P}_{2} \mathrm{O}_{5}$, and $\mathrm{K}_{2} \mathrm{O}$. The plants were sub-irrigated as needed.

\subsection{Rationale for Selection of Temperature and Light Regimes}

Previous research has shown that horseweed emerges throughout the year, late summer, fall, and spring, with maximum emergence occurring in the fall (September-October) and a new flush emerging in the spring (AprilMay) under field conditions [10]. Thirty-year average high and low temperatures for the months of October and April (representing peak horseweed emergence periods in fall and spring, respectively) at Stoneville, MS were $24^{\circ} \mathrm{C}$ and $11^{\circ} \mathrm{C}$, respectively [11]. Two temperature regimes were chosen, $24^{\circ} \mathrm{C} / 20^{\circ} \mathrm{C}$ as high and $18^{\circ} \mathrm{C} / 12^{\circ} \mathrm{C}$ as low temperature, in order to fall within this range, i.e., $11^{\circ} \mathrm{C}$ to $24^{\circ} \mathrm{C}$. Also, 30-year average day length during October was $11.4 \mathrm{~h}$ and during April was $13 \mathrm{~h}$ at Stoneville, MS [11]. Hence, a photoperiod of $13 \mathrm{~h}$ was chosen to coincide with the maximum temperature, i.e., $24^{\circ} \mathrm{C}$ in the high temperature regime and $18^{\circ} \mathrm{C}$ in the low temperature regime.

\subsection{Biological Parameters}

Horseweed growth was slow in the first four weeks following transplanting. Plants were left undisturbed for the four wk after transplanting to accommodate for acclimatization to conditions in the growth chamber. Beginning at four weeks after transplanting (5 WAE), four each of GR and GS plants were randomly selected from the two temperature regimes for measurement of growth parameters. Number of emerged leaves, rosette diameter (mean of horizontal and vertical diameter of rosette), rosette area, shoot fresh weight, root fresh weight, and shoot/root ratio were measured. Measurements were collected weekly from 5 to 11 WAE. Rosette area was measured using a stationary motor-driven leaf-area meter (LI-COR Biosciences, Lincoln, NE, USA). Shoot/root ratio was computed by dividing shoot fresh weight by root fresh weight to estimate proportional partitioning of resources to above ground and below ground plant parts. Collection of data on growth parameters was terminated $11 \mathrm{WAE}$ due to GS plants developing necrotic symptoms, but plants were allowed to grow. Thereafter, days to earliest bolting (production of a flowering stalk), flowering, and senescence were recorded for GR and GS plants from the two temperature regimes.

\subsection{Physiological Parameters}

All measurements were made on horseweed plants (5 to 6 WAE) that had rosettes containing 28 to 32 fully expanded leaves and were grown in the high temperature regime. Photosysnthesis, phenolics, and cell membrane thermostability data were recorded on nontreated and glyphosate-treated plants at 48 hours after treatment with glyphosate at $0.84 \mathrm{~kg} \cdot \mathrm{ae} \cdot \mathrm{ha}^{-1}$. Glyphosate was applied with a moving nozzle sprayer equipped with 8002E noz-

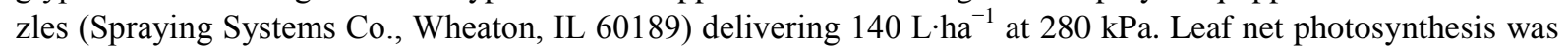
measured using a LI-6400 portable photosynthesis system as described earlier [12]. Leaf phenolic content was measured according to previously reported procedures [13]. Leaf cell membrane thermostability was measured following the methods of Kakani et al. [14]. Leaf tissue analysis was conducted at Mississippi State University Soil Testing Lab for measurement of Ca and Mg. In this method dry ash [15] was analyzed with an ICP spectrophotometer and atomic absorption.

\subsection{Statistical Analysis}

All experiments were setup in a completely randomized design with four replications per treatment and were 
repeated. The data represent the average of the two experimental trials since no experiment by treatment interaction occurred. All data were analyzed with SAS analytical software by subjecting to ANOVA to identify significant main effects and interactions. Data on vegetative growth parameters were further analyzed by fitting regression equations to raw data (SigmaPlot ${ }^{\circledR}$ 9.0, Systat Software Inc. Point Richmond, CA, USA) and means were plotted. Treatment means from the physiological experiments were separated using Duncan's new multiple range test at the $5 \%$ level of probability.

\section{Results and Discussion}

The two horseweed biotypes differed in all the variables evaluated. Both temperature and growth duration affected all aspects of horseweed plant growth and development. Temperature affected the horseweed biotypes differently. As growth progressed from 5 to $11 \mathrm{WAE}$, the number of leaves produced by the GR biotype was generally higher than that for the GS biotype (Figure 1). Averaged across temperature regimes and weekly measurements, number of leaves was 38 for the GR biotype and 36 for the GS biotype. Number of leaves was 40 in the high temperature regime and 35 in the low temperature regime, when averaged across biotypes and weekly measurements. Rosette diameter of the GR biotype, in general, was higher compared to the GS biotype (Figure 2). Averaged across the two temperature regimes and weekly measurements, rosette diameter was 9.1 in the GR biotype vs. $8.9 \mathrm{~cm}$ in the GS biotype. Averaged across biotypes and weekly measurements, rosette diameter was 9.3 and $8.7 \mathrm{~cm}$ under high and low temperature conditions, respectively.

The GR biotype had higher rosette area compared to the GS biotype (Figure 3). Averaged across temperature regimes and weekly measurements, rosette area was $51 \mathrm{~cm}^{2}$ under the high temperature regime and $43 \mathrm{~cm}^{2}$ under the low temperature regime. Averaged across the two temperature regimes and weekly measurements, rosette area was $50 \mathrm{~cm}^{2}$ and $44 \mathrm{~cm}^{2}$ in the GR and GS biotypes, respectively. Similarly, a GR common ragweed (Ambrosia artemisiifolia L.) ecotype had greater leaf area compared to a susceptible ecotype [16]. In contrast, a giant foxtail (Setaria faberi Herrm.) accession resistant to acetyl coenzyme A carboxylase (ACCase) inhibitors had similar leaf area over time compared to a susceptible accession under noncompetitive conditions in the field [17]. A triazine-susceptible common lambsquarters (Chenopodium album L.) biotype achieved greater leaf area than a resistant biotype [18]. The higher rosette area in the GR biotype is perhaps better reflected in the shoot

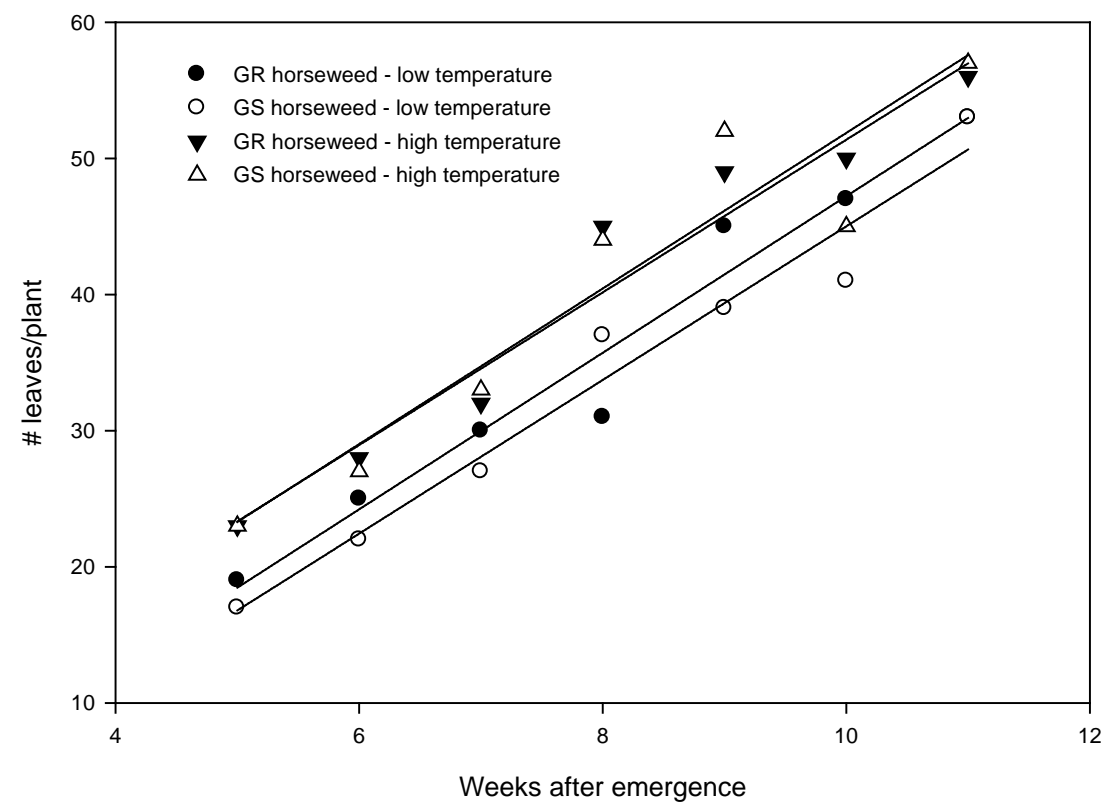

Figure 1. Number of leaves of glyphosate-resistant (GR) and -susceptible (GS) horseweed biotypes from Mississippi grown under two temperature regimes, high $\left(24^{\circ} \mathrm{C} / 20^{\circ} \mathrm{C}\right.$ day/night, $13 \mathrm{~h}$ light) and low $\left(18^{\circ} \mathrm{C} / 12^{\circ} \mathrm{C}\right.$ day/night, $13 \mathrm{~h}$ light). Regression equations: $(\bullet), \mathrm{y}=-10.3+5.8 \mathrm{x}, r^{2}=0.96, P<0.0001 ;(0), \mathrm{y}=-11.4+5.6 \mathrm{x}, r^{2}=0.96, P<0.0001$; $(\boldsymbol{\nabla}), \mathrm{y}=-5.3+5.7 \mathrm{x}, r^{2}=0.95, P=0.0002 ;(\Delta), \mathrm{y}=-4.7=5.6 \mathrm{x}, r^{2}=0.90, P=0.0012$. 


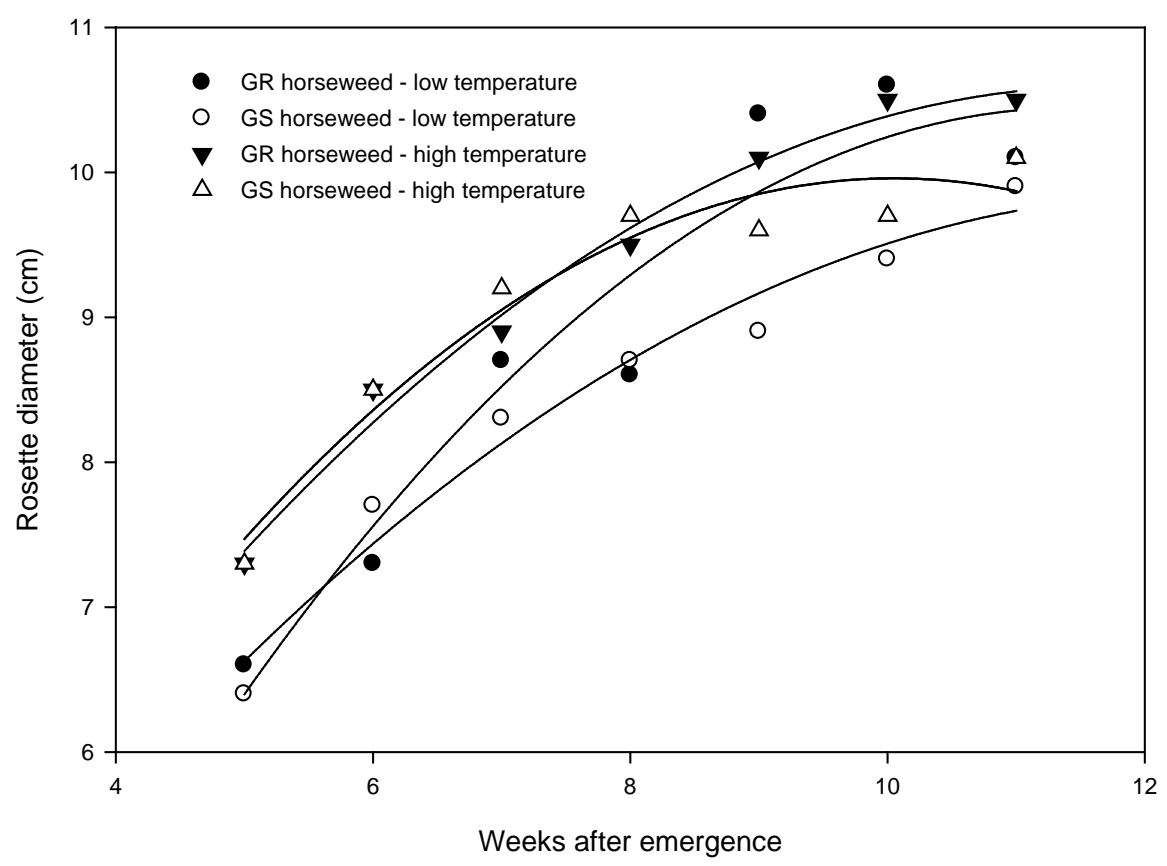

Figure 2. Rosette diameter of glyphosate-resistant (GR) and -susceptible (GS) horseweed biotypes from Mississippi grown under two temperature regimes, high $\left(24^{\circ} \mathrm{C} / 20^{\circ} \mathrm{C}\right.$ day/ night, $13 \mathrm{~h}$ light $)$ and low $\left(18^{\circ} \mathrm{C} / 12^{\circ} \mathrm{C}\right.$ day/night, $13 \mathrm{~h}$ light $)$. Regression equations: $(\bullet), \mathrm{y}=$ $0.83+1.5 \mathrm{x}-0.06 \mathrm{x}^{2}, r^{2}=0.97, P=0.0010 ;(\circ), \mathrm{y}=0.81+1.67 \mathrm{x}-0.07 \mathrm{x}^{2}, r^{2}=0.99, P=$ $0.0002 ;(\nabla), \mathrm{y}=-2.2+2.6 \mathrm{x}-0.13 \mathrm{x}^{2}, r^{2}=0.93, P=0.0045 ;(\Delta), \mathrm{y}=0.1+2.0 \mathrm{x}-0.1 \mathrm{x}^{2}, r^{2}$ $=0.95, P=0.0025$.

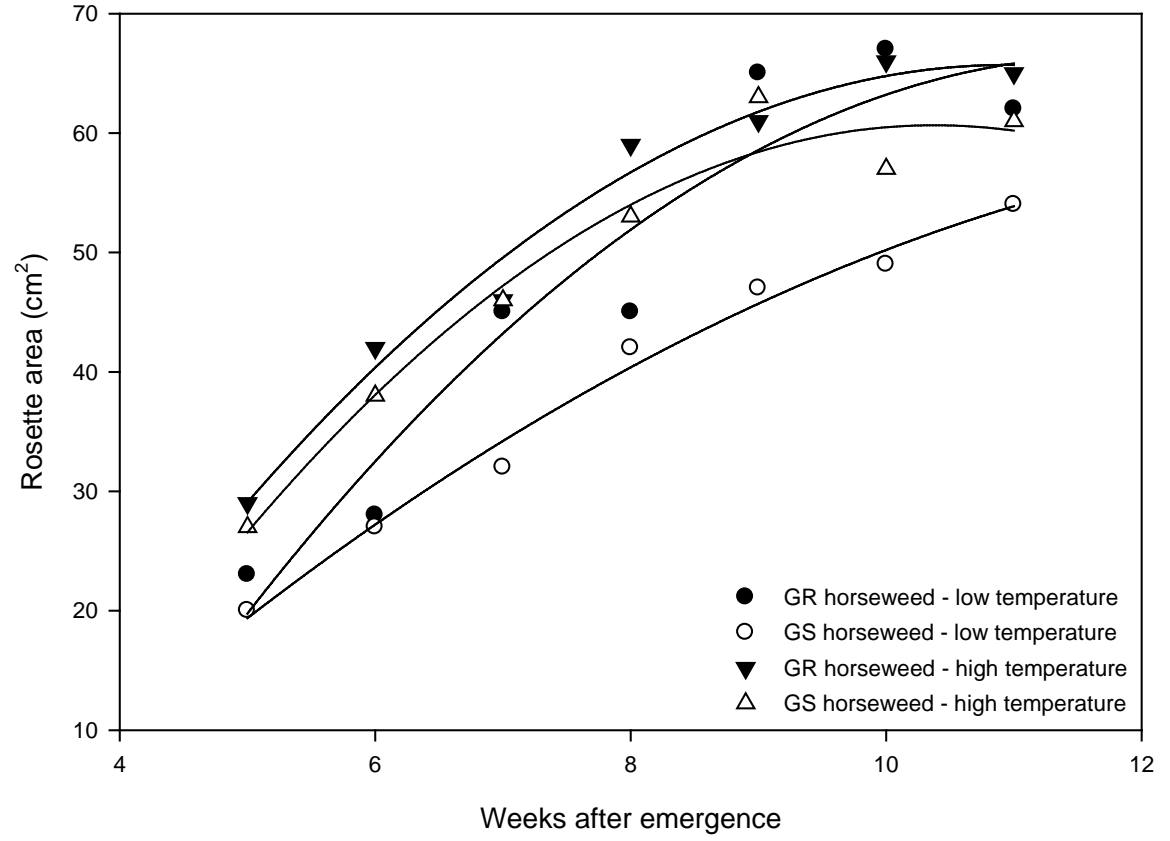

Figure 3. Rosette area of glyphosate-resistant (GR) and -susceptible (GS) horseweed biotypes from Mississippi grown under two temperature regimes, high $\left(24^{\circ} \mathrm{C} / 20^{\circ} \mathrm{C}\right.$ day/night, $13 \mathrm{~h}$ light) and low $\left(18^{\circ} \mathrm{C} / 12^{\circ} \mathrm{C}\right.$ day/night, $13 \mathrm{~h}$ light $)$. Regression equations: $(\bullet), \mathrm{y}=-74.3$ $+23.9 \mathrm{x}-1.0 \mathrm{x}^{2}, r^{2}=0.92, P=0.0065 ;(\circ), \mathrm{y}=-32.3+12.4 \mathrm{x}-0.42 \mathrm{x}^{2}, r^{2}=0.99, P=$ $0.0001 ;(\boldsymbol{\nabla}), \mathrm{y}=-58.4+22.7 \mathrm{x}-1.0 \mathrm{x}^{2}, r^{2}=0.98, P=0.0004 ;(\Delta), \mathrm{y}=-66.3+24.5 \mathrm{x}-$ $1.2 \mathrm{x}^{2}, r^{2}=0.96, P=0.0012$. 
fresh weight measurements, where the GR biotype had greater shoot fresh weight compared to the GS biotype (Figure 4). High rosette area in the GR biotype likely facilitated greater light interception and enhanced carbon assimilation, and possibly resulted in higher shoot fresh weight in the biotype compared to the GS biotype. Shoot fresh weight was $3.7 \mathrm{~g}_{\text {plant }}{ }^{-1}$ in the high temperature regime and $3.2 \mathrm{~g} \cdot$ plant $^{-1}$ in the low temperature regime, when averaged across biotypes and weekly measurements. Averaged across the two temperature regimes and weekly measurements, shoot fresh weight was 3.9 and $3.1 \mathrm{~g} \cdot \mathrm{plant}^{-1}$ in the GR and GS biotypes, respectively. Brewer et al. (2006) [16] reported that a GR common ragweed ecotype had greater biomass than a susceptible ecotype. Similarly, a GR horseweed biotype accumulated more dry weight than a GS biotype [19]. In contrast, final shoot biomass of triazine-susceptible Amaranthus blitoides (S.) Wats. plants was higher than that of triazine-resistant plants, rendering the resistant plants less fit than the wild type [20]. Also, a triazine-susceptible common lambsquarters biotype accumulated greater plant dry matter than a resistant biotype [18]. However, Anderson et al. (1996) [21] observed no difference in plant weight between triazine-resistant and -susceptible common waterhemp (Amaranthus rudis Sauer.) plants in the absence of interbiotypic competition. They reported that triazine-susceptible plants had a competitive advantage over the resistant plants when both were grown together. It is not clear whether the GR horseweed biotype can compete effectively with the GS biotype when grown in a competitive environment. A giant foxtail accession resistant to ACCase inhibitors had similar shoot dry biomass compared to a susceptible accession under noncompetitive conditions in the field [17].

Root fresh weight was higher in the GR biotype compared to the GS biotype (Figure 5). Averaged across the two temperature regimes and weekly measurements, root fresh weight was $4.3 \mathrm{~g} \cdot \mathrm{plant}^{-1}$ in the GR biotype and $3.5 \mathrm{~g} \cdot$ plant $^{-1}$ in the GS biotype. Root fresh weight was $3.5 \mathrm{~g} \cdot$ plant $^{-1}$ under the high temperature conditions and $4.2 \mathrm{~g} \cdot$ plant $^{-1}$ under the low temperature conditions. Higher root biomass at low temperature in horseweed may reflect buildup of reserves in the root for over-wintering and eventual switch to active metabolism during the following spring. Shoot/root ratio decreased in both GR and GS biotypes under both temperature regimes as growth proceeded from 5 to 11 WAE (data not shown). Future research should compare growth of GR and GS horseweed biotypes under natural conditions in the fall through spring to assess impact of environment on shoot and root biomass accumulation and root depth.

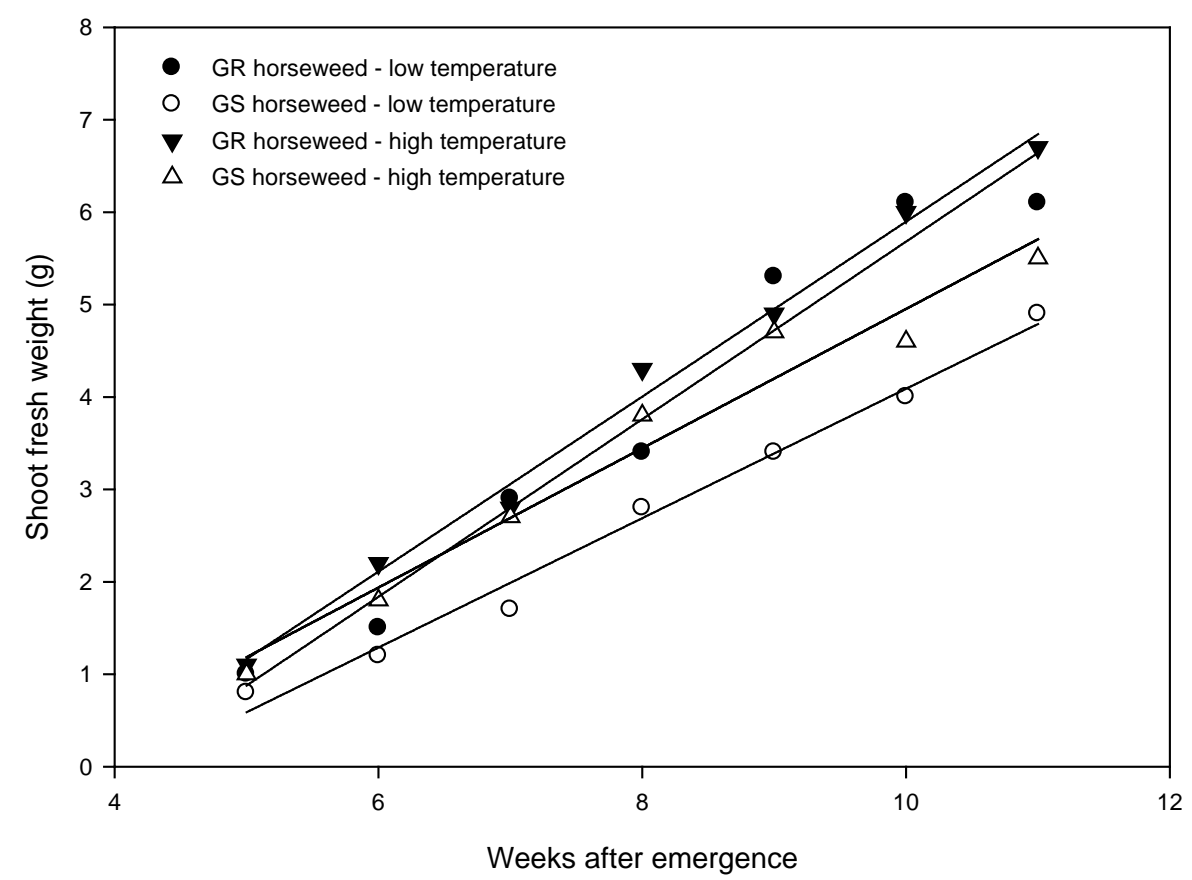

Figure 4. Shoot fresh weight of glyphosate-resistant (GR) and -susceptible (GS) horseweed biotypes from Mississippi grown under two temperature regimes, high $\left(24^{\circ} \mathrm{C} / 20^{\circ} \mathrm{C}\right.$ day/night, $13 \mathrm{~h}$ light) and low $\left(18^{\circ} \mathrm{C} / 12^{\circ} \mathrm{C}\right.$ day/night, $13 \mathrm{~h}$ light $)$. Regression equations: $(\bullet), \mathrm{y}=-3.9+$ $1.0, r^{2}=0.96, P=0.0001 ;(\circ), y=-2.9+0.7 \mathrm{x}, r^{2}=0.99, P<0.0001 ;(\nabla), y=-3.6+0.95 \mathrm{x}$, $r^{2}=0.99, P<0.0001 ;(\Delta), \mathrm{y}=-2.6+0.8 \mathrm{x}, r^{2}=0.96, P<0.0001$. 


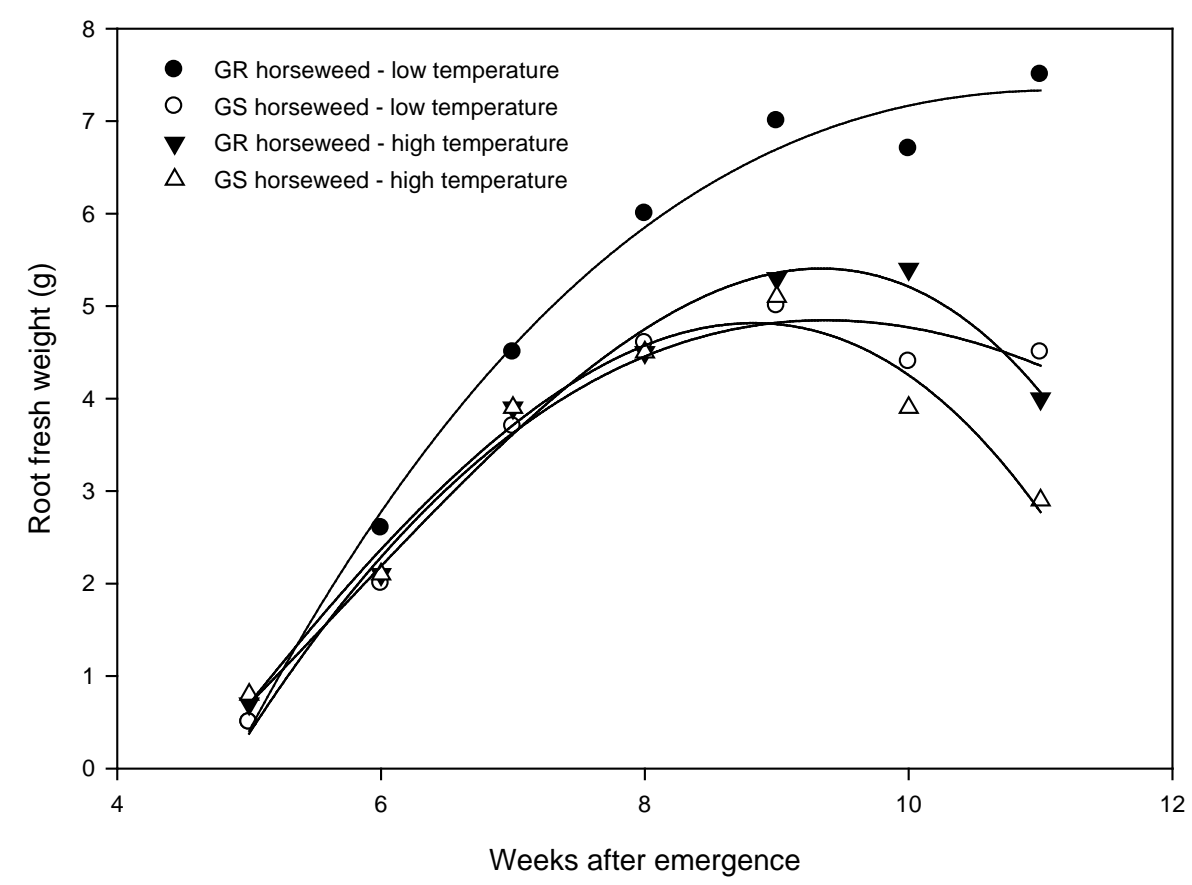

Figure 5. Root fresh weight of glyphosate-resistant (GR) and -susceptible (GS) horseweed biotypes from Mississippi grown under two temperature regimes, high $\left(24^{\circ} \mathrm{C} / 20^{\circ} \mathrm{C}\right.$ day/night, $13 \mathrm{~h}$ light) and low $\left(18^{\circ} \mathrm{C} / 12^{\circ} \mathrm{C}\right.$ day/night, $13 \mathrm{~h}$ light $)$. Regression equations: $(\bullet), \mathrm{y}=-22.4+$ $6.7 \mathrm{x}-0.5 \mathrm{x}^{2}+0.01 \mathrm{x}^{3}, r^{2}=0.99, P=0.0017 ;(\circ), \mathrm{y}=-19.4+5.9 \mathrm{x}-0.43 \mathrm{x}^{2}+0.01 \mathrm{x}^{3}, r^{2}=0.98$, $P=0.0044 ;(\nabla), \mathrm{y}=0.53-2.3 \mathrm{x}+0.7 \mathrm{x}^{2}-0.04 \mathrm{x}^{3}, r^{2}=0.99, P=0.0020 ;(\Delta), \mathrm{y}=-7.4+0.82 \mathrm{x}$ $+0.28 x^{2}-0.03 x^{3}, r^{2}=0.97, P=0.0073$.

The GS biotype bolted, flowered and began senescence earlier than the GR biotype under both low and high temperature regimes (Table 1, Figure 6). The GR biotype bolted later than the GS biotype and remained in this stage until termination of the experiment. Similar results were found when the GS and GR biotypes were grown under greenhouse conditions, where environmental factors were more variable compared to that in a growth chamber. Germination patterns of the GR and GS horseweed biotypes have not been compared, but an earlier report indicates no differences in field germination patterns between GR and GS horseweed populations [10]. Kochia biotypes from North Dakota and Kansas resistant to chlorsulfuron, an acetolactate synthase (ALS)-inhibitor, germinated earlier than respective susceptible biotypes at $8^{\circ} \mathrm{C}$, indicating lack of fitness differences between the resistant and susceptible biotypes [22].

There were no differences in leaf net photosynthesis between nontreated GR and nontreated GS plants. However, when treated with glyphosate, photosynthesis was reduced to a greater extent in the GS biotype (78\%) compared to the GR biotype (50\%) (Table 2). There was no difference in leaf phenolic content between GR and GS plants, regardless of glyphosate treatment (Table 2). Nontreated GS plants had higher cell membrane thermostability compared to GR plants (Table 2). However, glyphosate disrupted cell membrane stability of GS biotype (48\%) to a greater extent compared to GR biotype (27\%). Reduced translocation of glyphosate in the GR biotype compared to the GS biotype [9] had been anecdotally attributed to immobilization of glyphosate by divalent cations such as $\mathrm{Ca}^{2+}$ and $\mathrm{Mg}^{2+}$ in the leaf mesophyll cells. Higher levels of these elements in the GS biotype compared to the GR biotype (Table 2) did not support the above hypothesis.

In general, herbicide-resistant weed biotypes have been found to be equally fit as their susceptible counterparts with the exception of triazine-resistant weeds [23]. In many cases of ALS-inhibitor resistance there is a negligible fitness cost of the resistance gene in the absence of herbicide selection [24]. For example, ALS-inhibitor resistant Amaranthus spp. plants were equally fit compared to susceptible plants [25]. An exception was chlorsulfuron-resistant mouseearcress [Arabidopsis thaliana (L.) Heynh.] plants that produced 26\% fewer seeds than their susceptible counterparts [25]. Trifluralin-resistant green foxtail (Setaria glauca (L.) Beauv.) plants were almost, if not equally, as fit as trifluralin-susceptible plants based on Petri dish seed bioassays [26]. Rela- 
Table 1. Duration to initiate post-vegetative growth phases of glyphosate-resistant (GR) and -susceptible (GS) horseweed biotypes from Mississippi grown in growth chamber under two temperature regimes, low $\left(18^{\circ} \mathrm{C} / 12^{\circ} \mathrm{C}\right.$ day/night, $13 \mathrm{~h}$ light $)$ and high $\left(24^{\circ} \mathrm{C} / 20^{\circ} \mathrm{C}\right.$ day/night, $13 \mathrm{~h}$ light $)$.

\begin{tabular}{|c|c|c|c|c|}
\hline \multirow[b]{2}{*}{ Growth phase } & \multicolumn{2}{|c|}{ Low temperature } & \multicolumn{2}{|c|}{ High temperature } \\
\hline & $\mathrm{GS}^{\mathrm{a}}$ & GR & GS & GR \\
\hline & \multicolumn{4}{|c|}{ - wk after emergence ${ }^{-}$} \\
\hline Bolting & 18 & 22 & 16 & 20 \\
\hline Flowering & 28 & $-\mathrm{b}$ & 25 & - \\
\hline Senescence & 32 & - & 29 & - \\
\hline
\end{tabular}

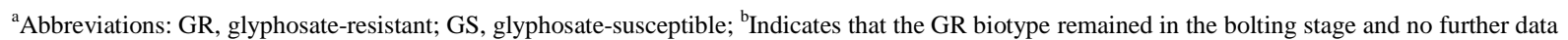
were collected.

Table 2. Physiological parameters of glyphosate-resistant (GR) and -susceptible

(GS) horseweed biotypes from Mississippi.

\begin{tabular}{ccc|}
\hline & \multicolumn{2}{c}{ Net Photosynthesis } \\
\hline Plant type $^{\mathrm{b}}$ & Nontreated & Glyphosate-treated \\
\hline & & Pnet $\left(\mu \mathrm{mol} \mathrm{CO} \mathrm{m}^{-2} \cdot \mathrm{s}^{-1}\right)$ \\
GR & $21 \mathrm{a}$ & $11 \mathrm{a}$ \\
GS & $18 \mathrm{a}$ & $4 \mathrm{~b}$ \\
\hline
\end{tabular}

Phenolics
$\left(\mu \mathrm{g} \cdot \mathrm{cm}^{-2}\right)$

$\begin{array}{lll}\text { GR } & 135 \mathrm{a} & 122 \mathrm{a} \\ \mathrm{GS} & 155 \mathrm{a} & 157 \mathrm{~b}\end{array}$

Relative injury $^{\mathrm{c}}$

(\%)

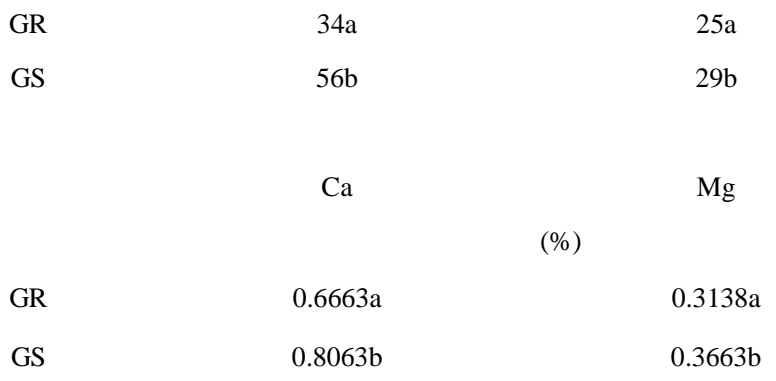

${ }^{a}$ Means followed by same letter within a column for each main effect are not significantly different at the $5 \%$ level of probability according to Duncan's new multiple range test; ${ }^{\mathrm{b}}$ Abbreviations: GR, glyphosate-resistant; GS, glyphosate-susceptible; ${ }^{\mathrm{c}}$ Relative injury $=100-\mathrm{CMT}$ (cell membrane thermostability.

tive fitness of triazine-resistant smooth pigweed (Amaranthus hybridus L.) populations was $42 \%$ to $70 \%$ of a triazine-susceptible population, for the fitness component of above-ground biomass production [27]. Fitness comparisons between GR and GS weed bioypes are extensively lacking in the literature.

\section{Conclusion}

There were some differences in biological and physiological growth processes between the GR and GS biotypes. 




Figure 6. Reproductive phase comparison of glyphosate-resistant (GR) and -susceptible (GS) horseweed biotypes from Mississippi grown under greenhouse (variable) and growth chamber (fixed) conditions.

Impact of growth differences between GR and GS horseweed biotypes reported in this study and possible fitness differences on performance of nonchemical and alternative chemical management programs need to be determined. Further research is required to determine whether interbiotypic or intracrop competitive differences exist between the GR and GS horseweed biotypes in the field. Both biotypes should be grown in replacement series under natural conditions and taken to maturity.

\section{References}

[1] Anonymous (2014) Conyza canadensis. http://en.wikipedia.org/wiki/Conyza_canadensis

[2] Buhler, D.D. (1992) Population Dynamics and Control of Annual Weeds in Corn (Zea mays) as Influenced by Tillage Systems. Weed Science, 40, 241-248.

[3] Vencill, W.K. and Banks, P.A. (1994) Effects of Tillage Systems and Weed Management on Weed Populations in Grain Sorghum (Sorghum bicolor). Weed Science, 42, 541-547.

[4] Brown, S.M. and Whitwell, T. (1988) Influence of Tillage on Horseweed (Conyza canadensis). Weed Technology, 2, 269-270.

[5] Van Gessel, M.J. (2001) Glyphosate-Resistant Horseweed from Delaware. Weed Science, 49, 703-705. http://dx.doi.org/10.1614/0043-1745(2001)049[0703:RPRHFD]2.0.CO;2

[6] Mueller, T.C., Massey, J.H., Hays, R.M., Main, C.L. and Stewart Jr., C.N. (2003) Shikimate Accumulates in Both Glyphosate-Sensitive and Glyphosate-Resistant Horseweed (Conyza canadensis L. Cronq.). Journal of Agricultural and Food Chemistry, 51, 680-684. http://dx.doi.org/10.1021/jf026006k

[7] Koger, C.H., Poston, D.H., Hayes, R.M. and Montgomery, R.F. (2004) Glyphosate-Resistant Horseweed (Conyza canadensis) in Mississippi. Weed Technology, 18, 820-825. http://dx.doi.org/10.1614/WT-03-218R

[8] Heap (2014) International Survey of Herbicide Resistant Weeds. http://www.weedscience.org/Summary/home.aspx

[9] Koger, C.H. and Reddy, K.N. (2005) Role of Absorption and Translocation in the Mechanism of Glyphosate Resistance in Horseweed (Conyza canadensis). Weed Science, 53, 84-89. http://dx.doi.org/10.1614/WS-04-102R

[10] Koger, C.H., Poston, D.H. and Eubank, T.W. (2005) Factors Affecting Germination of Horseweed (Conyza canadensis). Proceedings of Southern Weed Science Society, 58, 218.

[11] Boykin, D.L., Carle, R.R., Ranney, C.D. and Shanklin, R. (1995) Weather Data Summary for 1964-1993 for Stoneville, MS. Mississippi Agricultural and Forestry Experimental Station Technical Bull. 201. 49 p. Mississippi State University, 
Starkville.

[12] Reddy, K.R., Kakani, V.G., Zhao, D., Koti, S. and Gao, W. (2004) Interactive Effects of Ultraviolet-B Radiation and Temperature on Cotton Growth, Development, Physiology and Hyperspectral Reflectance. Photochemistry and Photobiology, 79, 416-427. http://dx.doi.org/10.1562/2003-11-19-RA.1

[13] Koti, S., Reddy, K.R., Lawrence, G.W., Reddy, V.R., Kakani, V.G., Zhao, D. and Gao, W. (2007) Effect of Enhanced UV-B Radiation on Reniform Nematode (Rotylenchus reniformis Linford and Oliveira) Populations in Cotton (Gossypium hirsutum L.). Plant Pathology Journal, 6, 51-59. http://dx.doi.org/10.3923/ppj.2007.51.59

[14] Kakani, V.G., Reddy, K.R., Koti, S., Wallace, T.P., Prasad, P.V.V., Reddy, V.R. and Zhao, D. (2005) Differences in in Vitro Pollen Germination and Pollen Tube Growth of Cotton Cultivars in Response to High Temperature. Annals of Botany, 96, 59-67. http://dx.doi.org/10.1093/aob/mci149

[15] Jones, J.B. and Steyn, W.J.A. (1973) Sampling, Handling, and Analyzing Plant Tissue Samples. In: Walsh, L.M. and Beaton, J.D., Eds., Soil Testing and Plant Analysis, Soil Science Society of America, Madison, 249-270.

[16] Brewer, C.E., Oliver, L.R. and Scott, R.C. (2006) Update: Arkansas Glyphosate-Resistant Common Ragweed. Proceedings of Southern Weed Science Society, 59, 188.

[17] Wiederholt, R.J. and Stoltenberg, D.E. (1996) Absence of Differential Fitness between Giant Foxtail (Setaria faberi) Accessions Resistant and Susceptible to Acetyl-Coenzyme A Carboxylase Inhibitors. Weed Science, 44, 18-24.

[18] Parks, R.J., Curran, W.S., Roth, G.W., Hartwig, N.L. and Calvin, D.D. (1996) Herbicide Susceptibility and Biological Fitness of Triazine-Resistant and Susceptible Common Lambsquarters (Chenopodium album). Weed Science, 44, 517522.

[19] Alcorta, M., Fidelibus, M.W., Steenwerth, K.L. and Shrestha, A. (2011) Competitive Effects of Glyphosate-Resistant and Glyphosate-Susceptible Horseweed (Conyza canadensis) on Young Grapevines (Vitis vinifera). Weed Science, 59, 489-494. http://dx.doi.org/10.1614/WS-D-10-00186.1

[20] Sibony, M. and Rubin, B. (2003) The Ecological Fitness of ALS-Resistant Amaranthus retroflexus and Multiple-Resistant Amaranthus blitoides. Weed Research, 43, 40-47. http://dx.doi.org/10.1046/j.1365-3180.2003.00315.x

[21] Anderson, D.D., Higley, L.G., Martin, A.R. and Roeth, F.W. (1996) Competition between Triazine-Resistant and -Susceptible Common Waterhemp (Amaranthus rudis). Weed Science, 44, 853-859.

[22] Thompson, C.R., Thill, D.C. and Shafii, B. (1994) Germination Characteristics of Sulfonylurea-Resistant and -Susceptible Kochia (Kochia scoparia). Weed Science, 42, 50-56.

[23] Gronwald, J.W. (1994) Resistance to Photosystem II Inhibiting Herbicides. In: Powles, S.B. and Holtum, J.A.M., Eds., Herbicide Resistance in Plants: Biology and Biochemistry, Lewis Publishers, Boca Raton, 27-60.

[24] Tranel, P.J. and Wright, T.R. (2002) Resistance of Weeds to ALS-Inhibiting Herbicides: What Have We Learned? Weed Science, 50, 700-712. http://dx.doi.org/10.1614/0043-1745(2002)050[0700:RROWTA]2.0.CO;2

[25] Purrington, C.B. and Bergelson, J. (1997) Fitness Consequences of Genetically Engineered Herbicide and Antibiotic Resistance in Arabidopsis thaliana. Genetics, 145, 807-814.

[26] Andrews, T.S. and Morrison, I.N. (1997) The Persistence of Trifluralin Resistance in Green Foxtail (Setaria viridis) Populations. Weed Technology, 11, 369-372.

[27] Jordan, N. (1999) Fitness Effects of the Triazine Resistance Mutation in Amaranthus hybridus: Relative Fitness in Maize and Soyabean Crops. Weed Research, 39, 493-505. http://dx.doi.org/10.1046/j.1365-3180.1999.00168.x 
Scientific Research Publishing (SCIRP) is one of the largest Open Access journal publishers. It is currently publishing more than 200 open access, online, peer-reviewed journals covering a wide range of academic disciplines. SCIRP serves the worldwide academic communities and contributes to the progress and application of science with its publication.

Other selected journals from SCIRP are listed as below. Submit your manuscript to us via either submit@scirp.org or Online Submission Portal.
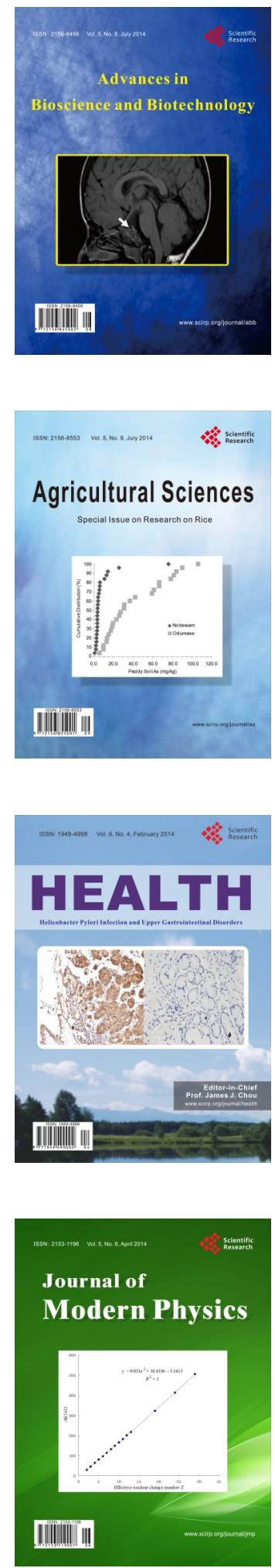
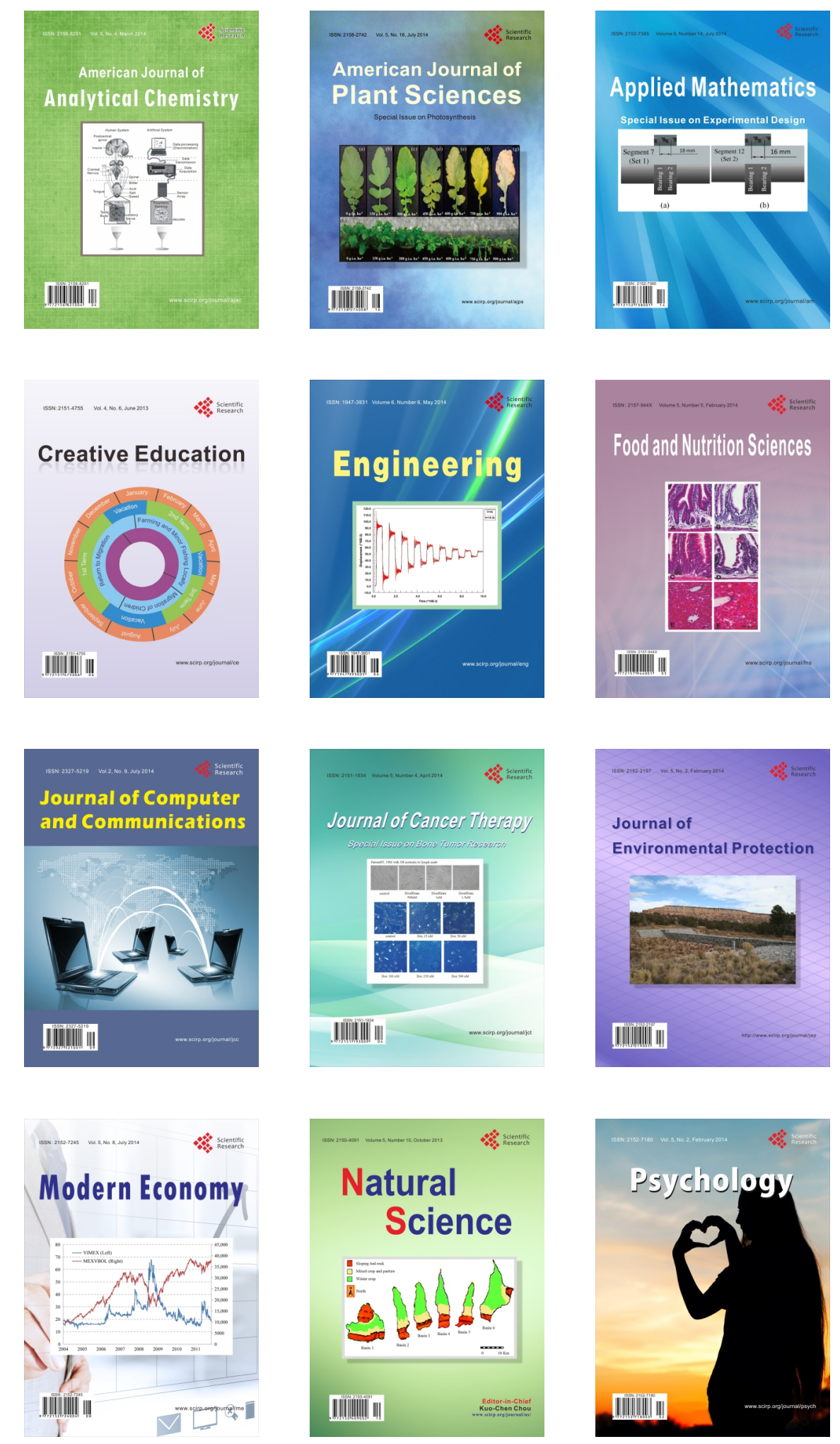